\title{
Phonological Rules in English and Its Application in Teaching
}

\author{
YANG Ren-ying \\ North China University of Technology, Beijing, China
}

\begin{abstract}
According to the requirements of The Syllabus for the English Majors in Higher School, English majors should grasp some phonological skills so as to practice English sound in a better way. For this, this paper aims to treat phonological rules, which can to a degree help the students to know the basic phonological rules and the variation rules in the natural conversation. However, the phonological rules in English are not universal.
\end{abstract}

Keywords: phonological rules, assimilation

\section{Introduction}

When we speak, we do not utter a series of individual units of sound. Rather, we speak in a continuous flow of sounds. In other words, the exact realization of the pronunciation is different from the adding-up of the individual units (Sapir, 2002, p. 90). But why are they not pronounced in accordance with its spelling and what are their underlying forms like? To a great extent, all these have to be specified by phonological rules.

Then what are the phonological rules and what is the main purpose? Briefly speaking, the rules of phonology are the study of the way to produce sounds which relate to each other in different contexts, and to the grammar and lexicon of a language, and the main task, according to Chomsky, is to provide a phonetic representation for each word on the basis of its phonological representation in the lexicon and the syntactic configuration in which it occurs at surface structure (Robins, 2000, p. 161). By justifying divergence between the lexical form and the phonetic form finally adopted, we shall see how the phonological rules carry out process of change (Crystal, 1997, pp. 164-165).

On the whole, the rules of the phonology can change the value of individual features, change the position of whole phonemes, and can delete features and add features. This paper aims to illustrate the four cases above. As the phonological rules differ from language to language, the illustrations in this paper are mainly English.

Before going on, there is one point worth mentioning, which helps to better understand the rules of phonology. In fact, speed and rhythm, on which the phonological rules are based, plays an important role in divergence between phonetic and lexical representation. For instance, the usual pronunciation of income is ['in $. \mathrm{k} \wedge \mathrm{m}]$, with primary stress on the first syllable, secondary stress on the second syllable, and a distinct syllabic division between $/ \mathrm{n} /$ and $/ \mathrm{k} /$. When we use the word as adjective, however, in the phrase income tax, the pronunciation may be ['in ،k^m 'tæks], but often it changes to ['inkəm 'tæks]. When income becomes part of the larger unit, income tax, the succession of three stressed syllables conflicts with our normal rhythmic patterns, and we weaken the second syllable from $[\Lambda]$ to $[\partial]$. The phrase as a whole telescopes within itself, and the amount

YANG Ren-ying, lecturer, M.A., English Department, College of Humanities and Law, North China University of Technology. 
of time available for the shift from one syllable to the next is shortened. The tongue, however, requires an appreciable amount of time to shift from the alveolar contact of $/ \mathrm{n} /$ to the velar contact of $/ \mathrm{k} /$. If the time is too short, the tongue anticipates the velar contact by shifting from $/ \mathrm{n} /$ to [ $\mathrm{\eta}]$, since the sequence $[\mathrm{\eta} \mathrm{k}]$ can be made with a single contact of the tongue, instead of the sequence of contacts required for $/ \mathrm{nk} /$.

\section{The Change of the Value of Individual Features: Assimilation}

One has probably noticed that the word cupboard which is obviously a compound of cup plus board, is pronounced as ['k^p 'bo:rd] instead of ['k^bəd]. It is assimilation in which the value of individual feature has changed that results in the phonetic change. Assimilation refers to a process whereby one sound is changed to a second under the influence of a third, or as Bloomfield points out that the position of the speech agents for the production of one word is altered to a position more like that of a neighboring sound (HU, 2002, p. 97). Three kinds of assimilation are divided.

- Regressive (or anticipatory), in which a sound is influenced by a following sound, e.g., ten bikes being pronounced as [tem baiks], ten men as /tem men/, and ten kings as [teך kIjz]. The above examples all involve a change in the place of articulation of nasal consonants. That is, when nasal alveolar $/ \mathrm{n} /$ is before velar $/ \mathrm{k} /, \mathrm{g} /$ or bilabial $/ \mathrm{b} /, / \mathrm{n} /$ will be changed into [ $\mathrm{g}$ ] or $/ \mathrm{m} /$ respectively. The pronunciation of the word ending in $/ \mathrm{n} /$ in isolation (citation form) only has one form, but in different contexts, there will be several variants. By means of phonological rule specifying the point of articulation of the phoneme concerned, the exact pronunciation can be predicted. Apart from the illustrated above, the phrase in court will be pronounced as ['in 'ko:t], and ten tops is pronounced as [ten tops], in which there is no change, for $/ \mathrm{n} /$ and $/ \mathrm{t} /$ are both alveolar. Not limited to the domain of the connected speech, this rule can also be evidenced in some words. For instances:

\begin{tabular}{|c|c|}
\hline bank [bæ门k] & anger ['æクgə] \\
\hline thank [өæךk] & hunger ['h^ygə] \\
\hline 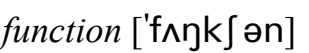 & England ['Inglend] \\
\hline
\end{tabular}

The similar case will happen to the sound /s/, and when we say rapidly this shield or horses shoes, /s/ will be assimilated into influenced by the palato-alveolar $\left[\int\right]$ or palatal $/ \mathrm{j} /$. For examples:

\begin{tabular}{|c|c|}
\hline horse shoe & ['ho: $\left.\iint u_{i}\right]$ \\
\hline this shield & [ðI $\left.\iint \mathrm{Ild}\right]$ \\
\hline was sure & [wə] 'Juə] \\
\hline Miss Young & {$\left[\mathrm{mI} \int \mathrm{j} \wedge \eta\right]$} \\
\hline
\end{tabular}

Another item, the voiceless can be assimilated to voiced by the voiced quality of the following vowels:

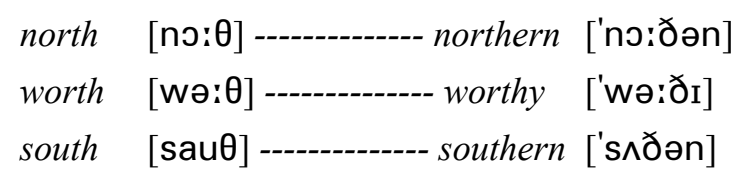

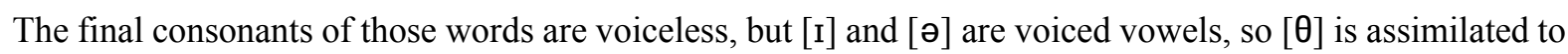
[ð].

In addition, a double assimilation, which functions to differentiate the meanings of a sentence, also falls into the group of regressive. In the phrase used to, the verb, used [ju:zd] has been assimilated to [ju:zt] by the following /t/, and meanwhile /z/ in [ju:zd] is assimilated to [ju:zt], and has the meaning of "formerly 
accustomed". The unassimilated pronunciation, with a pause between used and to, has kept the meaning "utilized". Thus the pen he used to [ju:stə] write with means the pen he was accustomed to write with, the pen he used to [ju:zd tə] write with means the pen he utilized for writing. Something similar occurs in the phrases have to and has to. For example: That's all I have to ['hæftə] do means that that's all I am compelled to do. That's all I have to ['hævtə] do means that that's all I have on had at the moment to do.

In oral American English, some phrases like going to, want to, got to, give me, roommate, for them, etc., will be pronounced in a different way from the pronunciations based on the spelling, i.e., ['gonə], ['wonə], ['gotə], ['gimi], ['rumi], [fə'rəm], in which all the phonetic changes are established on the basis of the phonological rule.

- Progressive, in which a sound is influenced by a preceding sound, e.g., lunch score becomes ['Innf 'Jko:]. Another instance is concerned with the pronunciation of the verb ending in $e d$. The inflectional ending -ed ends in voiced /d/ so long as the ending remains a separate syllable and /d/ follows either of the voiced sound [I]or [ə]], as in:

heated ['hitid] faded ['feidid]

But when inflectional -ed becomes non-syllabic, it remains /d/ after voiced sounds as in: begged [begd], loved [lıvd], gazed [geizd]. But it assimilates to the voiceless / $\mathrm{t} /$ after voiceless consonants, as in baked [beikt], reached [ri:t $\mathrm{t}]$, looked [lukt].

The same case with the plural forms of the noun or the third person singular form which ends in es or $s$, the pronunciation ends in voiced /z/ when the ending is syllabic, i.e., /z/ follows after the voiced sound[I], as in:

$\begin{array}{llll}\text { guesses } & \text { ['gesiz] } & \text { gazes } & \text { ['geiziz }] \\ \text { dishes } & {\left[\text { 'd } \mathrm{d} \int \mathrm{Iz}\right]} & \text { bridges } & \text { ['bridziz }]\end{array}$

When reduced to non-syllabic status, inflectional -es and -s remain /z/after voiced sounds, as in begs [begz], rubs [ $\mathrm{r} \wedge \mathrm{bz}$ ], but assimilate to the voiceless /s/ after voiceless consonants, as in bakes [beiks] and bikes [barks].

- Reciprocal (or coalescent), in which "the two sounds influence each other and combine to produce a single sound (fusion) which is a compromise between the two" (Crystal, 1997, p. 164). The word sure, for instance, was formerly pronounced [sjur]; but the sequence /sj/ required a more delicate adjustment than most speakers gave it. Consequently, the tongue slipped further back for $/ \mathrm{s} /$ and further forward for $/ \mathrm{j} /$, perhaps through some intermediated stage like [sj] or [sç], until the two sounds came together at the position for $\left[\int\right]$ and gave us our present pronunciation [Juə].

A similar reciprocal assimilation has taken place in vision ['vizən], from earlier ['vizjən]. In issue and a few similar words, Americans habitually used the assimilated ['i $\mathrm{f} u$ :]; the most frequent British pronunciation seems to be the unassimilated [' Isju:]. Similarly, the change from $/ \mathrm{hw} /$ to $/ \mathrm{w} /$ in such a word as when is a reciprocal assimilation in which $/ \mathrm{w} /$ takes its adjustment of tongue and lips from $/ \mathrm{w} /$ and its voiceless quality from $/ \mathrm{h} /$. This can be further shown in the connected speech, for example:

$\begin{array}{ll}\text { don't you } & \text { ['dəunt]u:] } \\ \text { would you } & \text { ['wudzu:] } \\ \text { did you } & \text { ['didzə] }\end{array}$




\section{Deletion Features}

In rapid speech, sounds may be left out, or elided, especially when they occur as part of a cluster of consonants. In English, alveolar consonants are commonly lost, especially at the ends of words, e.g., the final alveolar plosive would normally be dropped in such phrases as:

$\begin{array}{ll}\text { soft toys } & \text { [sof 'toiz] } \\ \text { soft features } & \text { [sof 'feðəz] } \\ \text { soft-en } & \text { ['sofən] }\end{array}$

The soft is usually pronounced [soft] in isolation and before words beginning with a vowel, as in soft eiderdown ['soft 'aidə,daun], but as -en before words beginning with a vowel and before the suffix -en, the final consonant of the citation form of the word is to be deleted. The process is not restricted to soft, for instances:

$\begin{array}{ll}\text { waste paper } & \text { [weIs 'peipə] } \\ \text { lost opportunity } & \text { ['lost 'opətju:nitI] } \\ \text { lost children } & \text { ['los 't } \text { J Ildren] } \\ \text { moist }- \text { en } & \text { ['moIsən] }\end{array}$

And the phrases next day, mashed potatoes, stopped speaking are the same cases. The initial weak vowel may elided in such phrases as go away and try again.

The antonym of assimilation is dissimilation, which also falls into the field of deletion features. In a phrase, when the ending phoneme is the same as the initial phoneme of the adjoining word, thus one of them will be deleted. For example: got to go becomes ['gotugəu]. In order to make it clear, we look at some words following. In February, library, secretary, stenographer, in which there are two $/ \mathrm{r} /$, for the convenience, one $/ \mathrm{r} /$ is left out. So the pronunciation becomes ['febju,erI], ['lai,beri], ['sekə'teri], [ste'nogəfə]. In government and environment, one $/ \mathrm{n} /$ is deleted.

Speaking of deletion feature, another case cannot be ignored, that is weakening. In normal conversation, words that express grammatical relationship are often produced with less force, in contrasts with the form in isolation or in a position which needs to put more emphasis. The following are examples which have shown the deletion features as a result of weakening.

$\begin{array}{lll}\begin{array}{ll}\text { word } \\ \text { a }\end{array} & \text { citation form } & \text { the weakened } \\ \text { and } & {[\mathrm{e}]} & {[ə]} \\ \text { could } & {[æ n \mathrm{~d}]} & {[\text { [ən, } \mathrm{n}]} \\ \text { had } & {[\mathrm{kud}]} & {[\mathrm{kd}]} \\ \text { him } & {[\mathrm{hæd}]} & {[\mathrm{d}]} \\ \text { is } & {[\mathrm{him}]} & {[\mathrm{Im}]} \\ \text { not } & {[\mathrm{iz}]} & {[\mathrm{s}, \mathrm{z}]} \\ & {[\mathrm{not}]} & {[\mathrm{nt}, \mathrm{n}]}\end{array}$

\section{Addition of the Features}

In this group, stress, tone, pitch, juncture, and other suprasegmental phonology will be concerned. As far as English is concerned, stress assignment plays an important part in the rules of phonology. Traditionally, stress in English is not easy to grasp because of the variation in the placement of stress in such items as: maca roon, 
de'velop, as paragus, 'penitently, where stress occurs on the last, penultimate, antepenultimate, and preantepenultimate syllables respectively; or the contrast in stress between compounds such as: yellow-hammer, blue-stocking, cheap-jack, and phrases containing apparently the same words: yellow - hammer, blue stocking, 'cheap - jack.

However, in a theory where phonological rules have access to syntactic and morphological information as well as purely phonological data, that is where phonology is interpretive, the position of stress becomes very largely predictable. Thus the difference among de velop, as paragus, penitently is a function of the difference among verb, noun, and adverb, the final stress in macaroon, is attributable to the long vowel in that syllable, and the difference between 'blue-stocking or blue stocking is due to their difference in syntactic structure, while both consist of an adjective followed by a noun, in the former these unit to form a compound noun, in the latter an NP, categories independently needed in the syntax. This last example is more significant than simple examples of word stress, as the latter, being finite, could be handled entirely within lexicon. The configurational differences between blue-stocking/blue stocking and George has plans to leave/George has plans to leave, however, can only be the result of phonological rules which have access to syntactic information; the set of possible forms to which such rules can apply is infinite, and therefore in principle not treatable by lexical listing.

Let us look at the transcriptions below, what do they represent? And how to read them?

(1) [hi:t $\int \mathrm{i}$ ts]

(2) [wot k $\mathrm{h}^{\mathrm{h}}$ ænı:t $\left.\int æ d\right]$ [ðætstıf]

Phonologically, there are two divisions, then with the help of juncture, we can distinguish the two kinds of meaning depending on the context.

(1) [hi:'t frits] he cheats vs. [hi:t']rits] heat sheets

(2) [wot $\mathrm{k}^{\mathrm{h}}$ æni: $\mathrm{t} \int$ 'æd] what can each add? vs. [wot $\mathrm{k}^{\mathrm{h}} \mathrm{nnI}_{\mathrm{i}} \mathrm{t}$ ' $\left.æ \mathrm{~d}\right]$ what can eat shad?

(3) ['ðæt 'st^f] that stuff vs. ['ðæts 'tıf] that's stuff

Also we make use of the intonation to judge the attitude or emotion of the speaker, the different pitch of utterance will bring the different effects on the same sentence and so on. This paper will not develop separately.

\section{The Change of the Position of the Whole Phoneme}

Now we come to the last case. A final group of divergence between lexical and phonetic representation is given by the relation of certain forms in adult and child speech. Presented with words such as wasp, desk, ask, and so on, children often metathesize the final two consonants to produce [wops], [deks], and [a:ks]. Given that this is a regular process and not merely the reflection of a mishearing on the part of the child, it must be accounted for by rule. The implication is that we need phonological rules that can change the position of phonemes.

\section{Conclusion}

In this paper, as mentioned at the beginning, the illustrations of phonological rules are restricted to English. So we could not help wondering whether the rules are absolute, implying double meanings, i.e., do they apply to all the sound patterns and connected speech in English? and do they apply to all the languages in the world or a large group of languages? As far as the evidence available concerned, the answer goes to the negative. It seems the theory is defective even in English itself, not mentioned all the languages. Take stress for example, certain 
words in English are exceptions to the stress rules. Extending the analysis of stress illustrated above, we can say that in nouns stress falls on the final syllable if it contains a long vowel, e.g., boutique; and on the penultimate syllable if the vowel in the final syllable is short, e.g., cabbage, torment, rabbit. In words of more than two syllable, c.f., as paragus, Ámerica, the stress may be further to the left if all vowels are short, also, the word abdomen ['æbdəmen], ab'domen [æb'dəumen], where stress shifts according to the length of the vowel. On analogy of this, words like ce'ment, bur lesque, ell ipse are predicted to be stressed on the first syllable, which is wrong. The similar problem, also arises in the field of assimilation.

Though the detailed rules of phonology in English do not correspond to the ones of the other languages but this paper considers, the four basic cases classified above do operate in a sense. At least, as far as Chinese and French concerned, there are similarities. In Chinese, the deletion features exist as well, especially in Fu Zhou dialect or Wu dialect, the consonant /-n/, /-k/, /-p/ will not be pronounced or will be weakened when following another Chinese character. And the following examples also illustrate this, in which a vowel is elided.

/women/__ _ _ _oufu/
/douf/

Liaison is a notable feature in French, which also has the deletion and addition features of the sound. When spoken in a normal speed, /1/ and /t/ are not pronounced. In the sentence Il y a quatre table, in which $/ 1 / \mathrm{in} i l$, /t/ in quatre, and $/ 1 /$ in table are left out. Another instance on addition, the final $t$ of $c^{\prime}$ 'est is pronounced when followed by a vowel. e.g., c'est impossible.

From above, we can see it is possible to establish a universal principle governing the use of sound in languages, which will contribute to the study of phonology and for the study of pedagogy. Though it is a tough task and needs much time and energy, this paper considers, it is necessary and beneficial.

\section{References}

Crystal, D. (1997). Cambridge encyclopedia of language: Part IV, The medium of language: Speaking and listening. Cambridge: Cambridge University Press.

HU, Z. L. (2002). Linguistics: An advanced course book. Beijing: Peking University Press.

Robins, R. H. (2000). General linguistics. Beijing: Foreign Language Teaching and Research Press.

Sapir, E. (2002). Language: An introduction to the study of speech. Beijing: Foreign Language Teaching and Research Press. 